\title{
Long-term cash flows of mandatory and voluntary pension funds in Croatia and their impact on asset allocation
}

EVA HORVAT, MBA*

MLADEN LATKOVIĆ, MSc*

Article $^{* *}$

JEL: G11, G18, G19, G23

https://doi.org/10.3326/pse.45.2.3

\footnotetext{
* The authors thank two anonymous reviewers for their helpful comments and suggestions for improvement of the article. The views expressed in this paper are solely those of the authors and do not necessarily represent those of the company in which they are employed.

${ }^{* *}$ Received: October 26, 2020

Accepted: January 22, 2021
}

\section{Eva HORVAT}

Raiffeisen Mandatory and Voluntary Pension Funds Management Company Plc, Petrinjska 59, 10000 Zagreb, Croatia

e-mail: eva.horvat@rmf.hr

ORCiD: 0000-0002-1000-2988

\section{Mladen LATKOVIĆ}

Raiffeisen Mandatory and Voluntary Pension Funds Management Company Plc, Petrinjska 59, 10000 Zagreb, Croatia

e-mail: mladen.latkovic@rmf.hr

ORCiD: 0000-0002-2463-0184 


\section{Abstract}

In this paper we analyse expected liquidity driven changes in asset allocation of Croatian mandatory and voluntary pension funds based on long-term cash flow projections. For mandatory pension funds, expected long-term cash flow are simulated taking into account the life-cycle scheme, changes in the default fund for undecisive newcomers, expected returns of funds and certain demographic and economic assumptions. Analogously, cash flow simulations of voluntary pension funds are simulated, with an additional scenario of short-term outflows due to the possibility of withdrawing earlier. The growing need for liquidity of pension funds is expected to impact their asset allocations through the endeavour for more liquid portfolios even in a baseline scenario. In the case of more severe assumptions of various parameters of the model, the liquidity-driven reallocation is expected to influence long-term returns of pension funds that experience negative or low net inflows, and subsequently lead to negative liquidity premium.

Keywords: pension funds, defined contribution system, life-cycle investing, asset allocation, liquidity

\section{INTRODUCTION}

The asset allocation of mandatory pension funds (MPF) in the Republic of Croatia is currently adjusted to the proxy life-cycle investment model introduced in 2014 (Mandatory Pension Funds Act, 2014). There are three categories of mandatory pension funds with different risk profiles. A category funds, which are the most risky, are structured as balanced risk profile funds with maximum allocation of $65 \%$ in equity markets $(80 \%$ if all alternative investment funds are used to generate equity exposure). Category B funds have a moderately conservative risk profile with a maximum allocation of $40 \%$ in equity markets $(50 \%$ if all alternative investment funds are used to generate equity exposure). Category $\mathrm{C}$ is represented by conservative pension funds that invest exclusively in fixed income instruments. Other investment limits for mandatory pension funds, along with limits that stipulate diversification among individual issuers, are mainly related to the exposure to different asset classes (e.g., maximum exposure to corporate bonds, municipal bonds or money market instruments) as well as currency exposure.

On the other hand, the asset allocations of Croatian voluntary pension funds (VPF) are not adjusted to the life-cycle investment model and generally not subject to asset allocation limits, aside from limits assigned by management companies themselves during the establishment of those funds through risk profiles predefined in their prospectus (Voluntary Pension Funds Act, 2014). However, on the market in the Republic of Croatia there are voluntary pension funds with different risk profiles, comparable with the risk profiles of the three available categories of mandatory pension funds. 
The main objective of pension funds management companies is to achieve the best risk/return outcome for pension funds, i.e. to optimize, in the long run, their expected returns vs. expected risk. However, in the investment decision process, pension funds management companies have to take into account the liquidity of their portfolios in order to be able to provide payments of accumulated savings for affiliates who fulfil the conditions for retirement. In addition to the liquidity risk of assets, i.e. the possibility of selling assets without significant price impact, there is also a cash flow liquidity risk, i.e. the possibility of misbalancing the short-term liquid assets of funds and their short-term liabilities that originate from payments of accumulated savings.

The legislative changes that introduced the proxy life-cycle scheme for mandatory pension funds in August 2014, and subsequent changes in enrolment process for new affiliates in October 2019, have significantly affected mandatory pension funds' cash flows. The latter change established three periods of accumulation: an affiliate is within A category until 10 years before retirement, then is transferred to a $\mathrm{B}$ category fund for 5 years and then to the $\mathrm{C}$ category for the last 5 years. The latest legislative change is equally as significant as the former one. If the fund category is not chosen by a new affiliate within a specified period, then Central Registry of Affiliates establishes their membership in a randomly chosen fund within the given category. Before the legislative change that started in October 2019, the default fund enrolment was to one of the B category funds and after that it was one of the A category funds. This means that the youngest cohort group of affiliates were enrolled into a fund dedicated to the older cohort group for more than 5 years after introduction of proxy life-cycle scheme.

Similar legislative changes that affect cash flows of voluntary pension funds were also introduced recently. The first change was introduced in 2014 with the possibility of activating variable annuity payments from a voluntary pension fund (unit-linked annuity), i.e. without the need for a member to withdraw the whole of their accumulated savings. The second change was introduced in 2019 with the extension of $3^{\text {rd }}$ pillar retirement age from 50 to 55 years, available, however, only to newcomers. Both of these changes facilitated the burden of possible substantial outflows for voluntary pension funds, either in providing an opportunity for members to choose a variable annuity, while keeping most of their savings at least for some time in a pension fund, or to postpone their decision on the withdrawal of accumulated savings. However, the ability to withdraw savings from the Croatian $3^{\text {rd }}$ pillar as early as at the age of 50 (only for members enrolled before January 2019 ) or 55 is still a substantial distance from the official 65 years of age for $2^{\text {nd }}$ pillar retirement (as of the time of writing this article).

These structures of possible transfers of accumulated savings in both pillars, moving savings from one fund to another or even withdrawing them much earlier than expected, might affect expected risk/return trade-off for $2^{\text {nd }}$ and $3^{\text {rd }}$ pillar pension funds due to the liquidity issues (a fund manager would usually try to minimize the 
money market portion of a pension fund portfolio in order to achieve the best risk/ return trade-off on the long run). The cash flow liquidity risk comes primarily from the misbalance of cash inflows from current members and outflows in the case of those who withdraw their savings. However, asset liquidity risk might arise from these cash flow imbalances, i.e. expected insufficient or even negative cash flows for a certain periods might force a changes in asset allocation of a pension fund from less liquid instruments to more liquid instruments in order to mitigate those possible imbalances. Current asset allocation of pension funds in Croatia (HANFA reports) shows a significant proportion of investment in domestic capital markets that have significantly lower asset liquidity than developed markets.

Therefore, given the constant requirements for maintaining adequate liquidity of pension funds in relation to their expected cash flows, in this article we analyse long-term cash flow dynamics and its possible impact on future pension funds asset allocations, and the expected decrease in their long-term returns due to a shift in asset allocation towards more liquid asset classes.

The article is organized as follows: in the second chapter we give a short overview of the Croatian $2^{\text {nd }}$ pillar and an analysis of legislative changes that influence cash inflows, MPFs' expected asset allocation and risk/return profiles and present simulations of long-term cash flows and their impact on MPFs' asset allocation. The third chapter gives a short overview of the Croatian $3^{\text {rd }}$ pillar with appropriate legislative changes that influence VPF cash inflows, expected asset allocation and risk/return profiles of VPFs and present simulations of cash flows and their impact on VPF asset allocation. Finally, the last chapter presents an analysis of the research results.

\section{MANDATORY PENSION FUNDS}

\subsection{SHORT OVERVIEW AND DEVELOPMENT}

Mandatory pension funds (MPF) in Croatia started operating with the pension reform in the form of the $2^{\text {nd }}$ pillar implemented in 2002 (Mandatory and Voluntary Pension Funds Act, 2002). At the beginning, in a new multi-pillar mandatory pension scheme only affiliates under 50 years of age could participate, with the additional possibility that those between 40 and 50 years of age could opt-out (a significant proportion of non-mandatory participants did not choose the multipillar scheme). Initially, fund management companies managed only one MPF dedicated to all cohort groups, i.e. irrespective of their age or personal affiliations to certain risk profiles.

Since payments of contributions to the $2^{\text {nd }}$ pillar are mandatory (in the amount of $5 \%$ of affiliate gross salary), and due to the restriction on participants' age imposed at the beginning, the net inflows to MPFs in first 15 to 25 years were expected to be strongly positive. As a result, and with the additional assistance from the gradual increase in inflows due to the rise in gross salaries in Croatia over time and strong positive realized funds' returns, MPFs overall assets experienced constant growth since their inception. 
Moreover, growth is expected to continue at a steady rate until a significant proportion of the first mandatory-in- $2^{\text {nd }}$ pillar cohort group, i.e. those who were 35 to 40 years of age at the beginning of the reform, start to retire, which is expected between 2027 and 2032. As of the end of 2019, total asset under management $(\mathrm{AuM})$ in the $2^{\text {nd }}$ pillar reached HRK 112.6 billion (EUR 15.1 billion), which represents $28 \%$ of Croatian GDP.

At the beginning of the $2^{\text {nd }}$ pillar pension scheme the steady positive net inflows enabled fund managers to engage in truly long-term investment policies - almost a textbook example of modern portfolio theory investment vehicle - with the possibility of earning an additional liquidity premium (resulting from buying and holding illiquid assets) above the premium resulting from strategic asset allocation decisions.

The first major shift in the $2^{\text {nd }}$ pillar pension scheme came with legislative changes in 2014 that introduced the proxy life-cycle pension scheme, i.e. different categories of MPFs - A, B and C, dedicated to specific cohort groups. In August 2014, one large MPF was split into three funds of different categories. Particular categories differ from each other according to their risk profiles, i.e. investment structures and the consequently expected long-term returns. Furthermore, affiliates cannot choose the funds' categories arbitrarily due to restrictions on age imposed by the risk profile of a fund. The main characteristics of A, B and C categories of MPFs are shown in table 1.

\section{TABLE 1}

Main characteristics of different mandatory pension funds' categories

\begin{tabular}{|c|c|c|c|c|}
\hline \multirow{2}{*}{\multicolumn{2}{|c|}{$\begin{array}{l}\text { Membership } \\
\text { Up to number of years until retirement }\end{array}$}} & \multirow{2}{*}{$\frac{\text { Category A }}{10}$} & \multirow{2}{*}{$\frac{\text { Category B }}{5}$} & \multirow{2}{*}{$\begin{array}{c}\text { Category C } \\
\text { No } \\
\text { restrictions } \\
\end{array}$} \\
\hline & & & & \\
\hline Risk profile & & Balanced & $\begin{array}{c}\text { Moderately } \\
\text { conservative }\end{array}$ & Conservative \\
\hline \multirow{3}{*}{$\begin{array}{l}\text { The most } \\
\text { important } \\
\text { investment } \\
\text { limits }\end{array}$} & $\begin{array}{l}\text { Minimum percentage of the } \\
\text { fund's net assets in } \\
\text { government debt securities } \\
\text { and money market instruments }\end{array}$ & 30 & 50 & 70 \\
\hline & $\begin{array}{l}\text { Maximum percentage of the } \\
\text { fund's net assets in equity }\end{array}$ & 65 & 40 & $\begin{array}{l}\text { Investment } \\
\text { in equity is } \\
\text { not allowed } \\
\end{array}$ \\
\hline & $\begin{array}{l}\text { Minimum percentage of the } \\
\text { fund's net assets denominated } \\
\text { or settled in domestic currency } \\
\text { (HRK) }\end{array}$ & 40 & 60 & 90 \\
\hline
\end{tabular}

Source: Mandatory Pension Funds Act (2014). 
However, the split into the A-B-C scheme in 2014 did not turn out to be optimal as the majority of affiliates stayed in the B fund, the default option for those who fulfilled the age condition. Only a handful of affiliates opted for the riskier A category fund $(0.28 \%$ of total membership) despite public recommendations that younger cohort groups should opt for that category. The split resulted in only $0.52 \%$ of AuM being placed in category A funds and $2.2 \%$ in category $\mathrm{C}$ funds.

Moreover, the default option for newcomers who did not decide to choose a fund in a short period after first employment (subsequently redistributed randomly by a central registry to one of the funds managed by the different companies) within the 2014 legislative changes remained category B funds, although the life-cycle scheme design clearly recommends that the youngest cohort groups should start with the riskiest choice. In addition, the vast majority of newcomers (around 99\%) historically did not choose a fund by themselves, meaning that effectively almost all of them were enrolled in one of the B category funds. By the end of September 2019 , as a result of the initial split and redistribution choices, the AuM of category A funds reached only the very modest $0.71 \%$ of total assets, while category $\mathrm{C}$ funds reached an also very modest $5.01 \%$ of total assets. The redistribution to a category B fund remained in force for more than 5 years until the 2019 legislative changes, starting with the October 2019 redistribution, diverted no-fund-decisionnewcomers to one of the A category funds.

As a result of the introduction of the life-cycle scheme in 2014 and subsequent changes in redistribution policy in 2019, and together with the retirement of the first mandatorily-in- $2^{\text {nd }}$ pillar cohort group, in the next decade a complex situation with cash flows is expected to appear between different MPFs categories. It is our goal to analyse expected cash flows in the $2^{\text {nd }}$ pillar, through simple approximations that will reveal the major trends, and subsequently estimate the liquidity-implied changes in asset allocation for different MPF categories. Also, we estimate that the current liquidity of domestic assets are one or two orders of magnitude smaller than the liquidity of assets on developed markets, which might imply asset reallocation towards developed markets and subsequently a different risk/return trade-off with the possible outcome of a loss of liquidity premium in the long term.

The same reasoning of liquidity-implied changes in asset allocation for VPFs is analysed in subsequent chapters. Therefore, our next task is to establish a reasonable choice of asset allocation structures, i.e. strategic asset classes, for a particular type of a pension fund, along with their risk/return trade-offs and correlations between them.

\subsection{ASSET ALLOCATION OF MANDATORY PENSION FUNDS}

The asset allocation structure of MPFs from 2002 onward shows a traditionally high share of domestic investments, particularly in Croatian government bonds. As of the end of 3Q 2020, more than $80 \%$ of funds' assets in category B and C funds are invested in the domestic market and for category A funds that figure is close to $70 \%$. One of the main reasons for the high inclination to domestic assets 
in MPFs is certainly the limit for currency exposure (see table 1). However, we also note a significant out-performance of Croatian government bonds in the period from April 2002 until September 2020, in terms of risk/return trade-off, with respect to other asset classes, i.e. their realized return vs. risk ratio was three times higher ${ }^{1}$ than for foreign equity or fixed income developed market asset classes. More on the efficiency and performance of Croatian mandatory pension funds can be found elsewhere (Novaković, 2015; Matek and Radaković, 2015; Matek, Lukač and Repač, 2016; Draženović, Hodžić and Maradin, 2019).

The share of assets invested in equities in relation to assets invested in other asset classes also shows that MPFs did not utilise the maximal exposure to equities allowed by investment limits. As of the end of 2Q 2020, the exposure of category A funds to equities was around $45 \%$ and that of B funds around $25 \%{ }^{2}$ (C funds cannot invest in equities). Although MPFs have recorded a slight increase in exposure to equities over time, they continued to invest predominantly in fixed income securities.

In order to simplify further analysis, and taking into account the current as well as expected asset allocation of MPFs, we are going to use the simple breakdown of asset allocation in terms of four major asset classes (i.e., they will be treated as distinctive risk factors due to different expected premiums, risks and low correlations): domestic fixed income, domestic equity, foreign fixed income and foreign equity. Furthermore, in order to calculate pension funds expected net inflows, accumulated savings, expected returns and risks, below we define expected long-term returns and volatilities of these four risk factors as well as their mutual correlations.

The expected long-term returns of pension funds mostly depend on the strategic asset allocation of their portfolios, i.e. on the allocation to fixed income securities (bonds) and equity securities (shares) in their portfolios. These expectations can be derived either through analysing the average realized returns over previous periods (Dimson, March and Staunton, 2020) or through analysing drivers of their future values. In addition, one might utilize expectations from various market participants in order to establish their own expectations. Here, we use the last two methods, due to the short history of the domestic market and expected changes in risk premiums for domestic asset classes due to the convergence of Croatia toward the European Monetary Union.

Expected returns and volatilities for selected asset classes are presented in table 2. For foreign equity and fixed income markets, estimations are based on market consensus (see, e.g., Horizon Actuarial Services, 2020), while for the Croatian

\footnotetext{
${ }^{1}$ Measured by proprietary Croatian government bonds index of Raiffeisen Mandatory and Voluntary Pension Fund Management Company vs. indices for broad developed equity and fixed income markets. In a period April 2002 till September 2020, Croatian government bonds exhibited 6.9\% annual rate of return vs. $4.5 \%$ annual volatility.

${ }^{2}$ Estimation according to semi-annual reports of mandatory pension funds' portfolios published on management companies' web pages.
} 
market an estimate of premiums is used with respect to their developed market counterparts in order to account for the higher expected risk of Croatian assets. Assumptions about the correlations are given in table 3, and they are estimated by observing the trends in the correlations of returns on various asset classes as well as from those derived from various market participants.

\section{TABle 2}

The expected returns and volatilities for fixed income and equity asset classes on Croatian (HR) and developed (DM) capital markets (in \%, annualized)

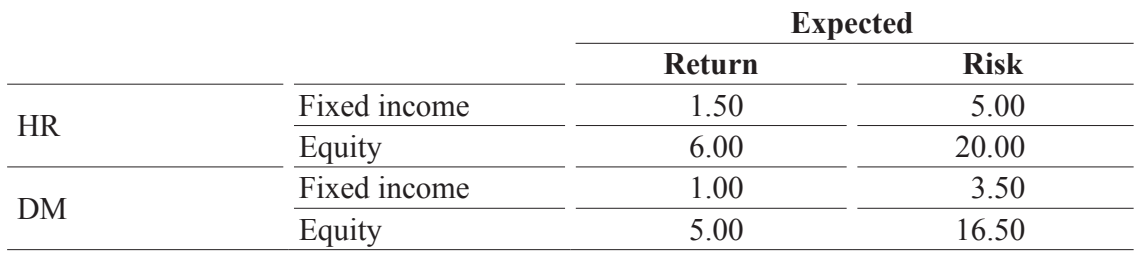

Source: Estimations by the authors.

TABle 3

Assumptions for correlations between asset classes

HR

DM

\begin{tabular}{|c|c|c|c|c|c|}
\hline & & Fixed income & Equity & Fixed income & Equity \\
\hline \multirow{2}{*}{ HR } & Fixed income & 1.00 & 0.10 & 0.70 & 0.20 \\
\hline & Equity & 0.10 & 1.00 & 0.10 & 0.50 \\
\hline \multirow{2}{*}{ DM } & Fixed income & 0.70 & 0.10 & 1.00 & -0.10 \\
\hline & Equity & 0.20 & 0.50 & -0.10 & 1.00 \\
\hline
\end{tabular}

Source: Estimations by the authors.

Taking into account the regulatory limits on the exposure to equity for MPFs of various categories (see table 1), we assume the targeted asset allocation in equity and fixed income asset classes for funds $\mathrm{A}, \mathrm{B}$ and $\mathrm{C}$. The allocation to equity is arbitrarily increased for category A and B funds from their current asset allocations, i.e. we do not want to match them, rather to adjust them to possibly higher values in order to analyse the impact of liquidity in more adverse situations. Assumptions about the asset allocations of MPFs are shown in table 4.

\section{TABLE 4}

Expected asset allocation of MPFs in equity and fixed income asset classes (in \% of funds' assets)

\begin{tabular}{lll} 
A & B \\
\hline Equity & 60 \\
Fixed income & 40
\end{tabular}$-\frac{\text { C }}{30}-\frac{0}{70}-\frac{100}{2}$

Source: Estimations by the authors. 
For category A fund we have selected a more balanced asset allocation, while the allocation for the category $\mathrm{C}$ fund is completely conservative. Furthermore, we assume that funds invest their assets in Croatian and foreign markets, according to the allocation shown in table 5. Also, we can notice an increased exposure to domestic market vs. developed markets, as in the current situation. The larger proportion of developed market equity in category B fund than of domestic equity comes from the fact that current assets of those funds are too large to create an effective exposure on the relatively low capitalization of the Croatian market.

\section{TABLE 5}

Expected asset allocation of MPFs to Croatian (HR) and developed market (DM) asset classes (in \% of funds' assets)

\begin{tabular}{|c|c|c|c|c|}
\hline & & $\mathbf{A}$ & B & C \\
\hline \multirow{2}{*}{ HR } & Fixed income & 30 & 60 & 90 \\
\hline & Equity & 30 & 10 & 0 \\
\hline \multirow{2}{*}{$\mathrm{DM}$} & Fixed income & 10 & 10 & 10 \\
\hline & Equity & 30 & 20 & 0 \\
\hline Total & & 100 & 100 & 100 \\
\hline
\end{tabular}

Source: Estimations by the authors.

Based on the assumptions on expected real returns, risks, correlations and the asset allocations of MPFs portfolios, shown in tables 2 to 5 , and by using the equation for portfolio total return, $R_{P}$, and portfolio risk, $\sigma_{P}$ :

$$
\begin{gathered}
R_{P}=\sum_{i} w_{i} R_{i} \\
\sigma_{P}^{2}=\sum_{i j} w_{i} w_{j} \sigma_{i} \sigma_{j} \rho_{i j}
\end{gathered}
$$

where $w_{i}$ represents the share of an asset class in the portfolio, $R_{i}$ and $\sigma_{i}$ are its expected return and expected risk respectively, while $\rho_{i j}$ is the expected correlation between the $i$ th and $j$ th asset classes, we calculate the expected returns and risks for a particular fund (table 6).

\section{TABLE 6}

\begin{tabular}{|c|c|c|c|}
\hline Expected & $\mathbf{A}$ & B & $\mathrm{C}$ \\
\hline Risk & 9.91 & 6.10 & 4.75 \\
\hline Return & 3.85 & 2.60 & 1.45 \\
\hline
\end{tabular}

The expected returns and volatilities of MPFs (in \%, annualized)

Source: Authors'own calculations.

The results presented in table 6 show that the expected returns and volatilities are the highest for a category A fund, and by decreasing the share of equity in the portfolios of category $\mathrm{B}$ and $\mathrm{C}$ funds their expected returns and risks both decline. 
In order to establish expected long-term cash flows for MPFs, first we have to analyse expected enrolment rate in the $2^{\text {nd }}$ pillar scheme and subsequently determine the retirement rate. Our analysis is based on the data taken from membership database of Raiffeisen Mandatory Pension Funds. However, we assume that the sample size of those funds (market share $29.4 \%$ as of 3Q 2019) is high enough for conclusions drawn from this source to be applicable to all Croatian MPFs.

For current members we use their expected retirement age from the database and assume they are following the life-cycle path determined by the law. In other words, a member will stay in category A fund until they reach 55 years of age, then they are transferred to B category fund for next 5 years, until they reach 60 years of age, and finally at 60 they are settled in a C category fund until retirement at 65 . Although certain members could choose another path through the life-cycle scheme, taking earlier retirement or dying earlier, we assume that the number of those members is not significant for this analysis.

Moreover, for the sake of simplicity, we assume that all future newcomers in the $2^{\text {nd }}$ pillar scheme have the same age of 25 and that they will follow the same life-cycle path described above. In reality newcomers have a wide range of ages when they join the $2^{\text {nd }}$ pillar. However, that would only smooth our abrupt transition scheme and would not contribute significantly to membership dynamics over the long term.

In order to address long-term demographic development that presumably can strongly influence the overall sustainability of a pension scheme, in the simulation of the membership base we use a parameter that describes the rate of increase of newcomers to the system, i.e. the enrolment rate. In a baseline scenario, the annual enrolment rate is set to $0.3 \%$. Positive growth rate is the result of optimistic labour participation that assumes effective labour market policies and immigration, the details of which are not the subject of this paper.

Results of simulation for long-term membership dynamics for the $2^{\text {nd }}$ pillar are shown in figure 1. From figure 1 we see that legislative changes from 2014 and 2019 have a strong impact on membership base for a particular category of MPF. As soon as category B funds lost their default choice for no-fund-decision-newcomers in October 2019, their membership base started to decline at a considerable rate, which we expect to continue until 2050, when it will slow down due to transition of current newcomers in category A funds to category B funds. The situation for the membership base of category A funds is inverse to that of the B category. On the other hand, category $\mathrm{C}$ funds have not had any significant long-term change in their membership base as they were not affected by legislative changes.

From membership dynamics, we can construct expected long-term inflows and outflows for a particular MPF category. Here, we also assume a constant longterm increase in average gross salary, without attempting to address a possible increase of contribution rate (unchanged at $5 \%$ contribution of gross salary to the 
$2^{\text {nd }}$ pillar since inception), and set that parameter to $1.0 \%$ as a baseline scenario. We also take into account the different average contributions in particular categories, e.g. members of category $\mathrm{C}$ fund have the largest contributions to MPFs due to their expected higher salaries. On the other hand, analysis of expected outflows takes into account accumulated savings for particular cohort groups, modelled with the expected long-term returns derived in the previous chapter. More on methods used to calculate accumulated savings can be found elsewhere (Šorić, 2000; Latković and Liker, 2009; Kovačević and Latković, 2015).

\section{Figure 1}

Realized and expected long-term membership dynamic (number of members at the end of period) for $2^{\text {nd }}$ pillar proxy life-cycle scheme in Croatia

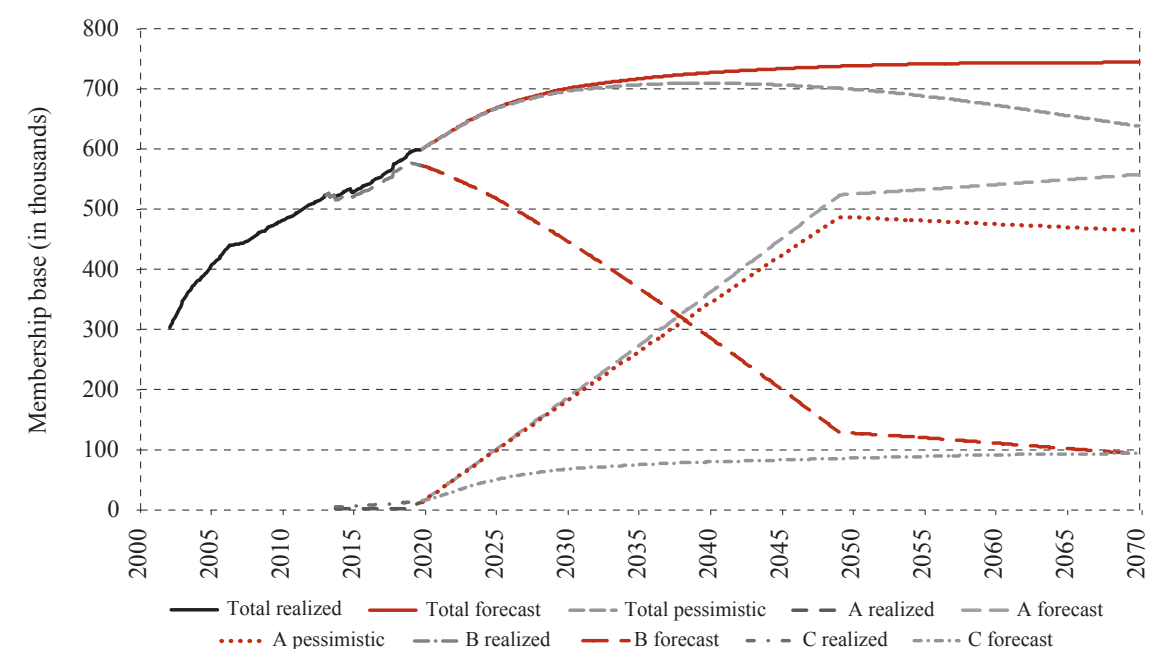

Source: Authors'own calculations.

Results of simulation for long-term net inflows for the $2^{\text {nd }}$ pillar are shown in figure 2. From figure 2 we see that after October 2019 there is a steady increase in net inflow for category A funds, which abruptly finishes in 2050 when, according to our assumptions on membership dynamics, the majority of 2019 cohort group of newcomers will be transferred to category B funds. In reality, the transition will not be as abrupt as our simulation shows, rather, a smoothed version of the transition is expected to occur due to the different ages of newcomers when they join the $2^{\text {nd }}$ pillar. After this transition period, we expect that net inflows to category A funds will saturate to some steady positive level. We also note that this conclusion depends on the assumptions of a net positive effect due to the favourable combination of the rate of change in number of newcomers to the $2^{\text {nd }}$ pillar, rate of change of gross salaries and long-term returns of category A funds. Below, we will discuss some unfavourable scenarios in order to understand the possible reasons for asset reallocations in category A funds due to liquidity issues. 
Realized and expected long-term net inflows (in $m n$ HRK) to $2^{\text {nd }}$ pillar proxy life-cycle scheme in Croatia

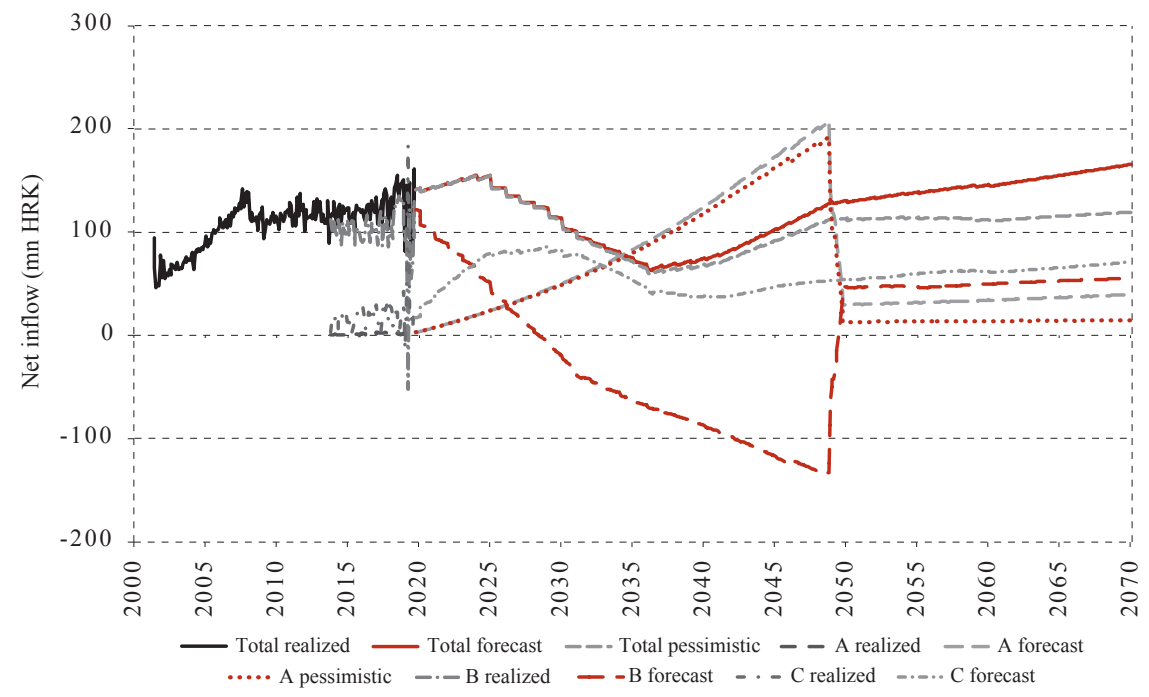

Source: Authors'own calculations.

On the other hand, net inflow for category B funds looks almost like a mirror reflection of net inflow for category A funds. No longer supported by no-fund-decisionnewcomers, and approaching the period when the first mandatory-in-the $2^{\text {nd }}$ pillar cohort group will have to be transferred to category $\mathrm{C}$ funds, net inflow of category $\mathrm{B}$ funds gradually dries up and becomes negative up to the point when suddenly the cohort group of 2019-newcomers will start to transfer their accumulated savings to category B funds. After this transition period, we also expect that net inflows to category B funds will saturate to some steady positive level and, as is a case for category A funds, be strongly dependent on the favourable combination of the parameters mentioned above. As with category A funds, in reality the transition will not be as abrupt as depicted and a smoothed version of the transition is expected to occur.

Net inflow for category $\mathrm{C}$ funds turns out to be more complex as those funds are going through several phases. In the next several years, category $\mathrm{C}$ funds will exhibit stronger net inflows due to transfers of members from the cohort group aged between 40 and 50 at the start of the reform in 2002: the distribution of membership age for this cohort group decreases rapidly when approaching the age of 50 due to the recommendations from the authorities in 2002 to opt out of the $2^{\text {nd }}$ pillar if personal salaries are not high enough. After this cohort group retires, the next, first mandatory-in-the $2^{\text {nd }}$ pillar, cohort group starts to increase outflows due to its longer period of accumulation in category B funds. Finally, after 2040, when mandatory-in-the $2^{\text {nd }}$ pillar newcomers of the 2002 cohort group start to arrive in category $\mathrm{C}$ funds, and all effects that can be attributed to the way the $2^{\text {nd }}$ pillar was formed in 2002 vanish, net inflows start to stabilize at a certain level, as in category A and B funds. 
The influence of net inflow on MPFs net asset value can be seen in figure 3. Due to the negative expected net inflows, the value of assets for category B funds is expected to gradually saturate until 2050, while at the same time category A funds are expected to rise with a strong rate until the same year. After 2050, both A and B, are expected to experience increased outflows. Eventually, it is expected that category A funds will at some point overtake assets of category B funds due to the higher expected returns.

\section{Figure 3}

Realized and expected net asset values (in mn HRK) for $2^{\text {nd }}$ pillar proxy life-cycle scheme in Croatia

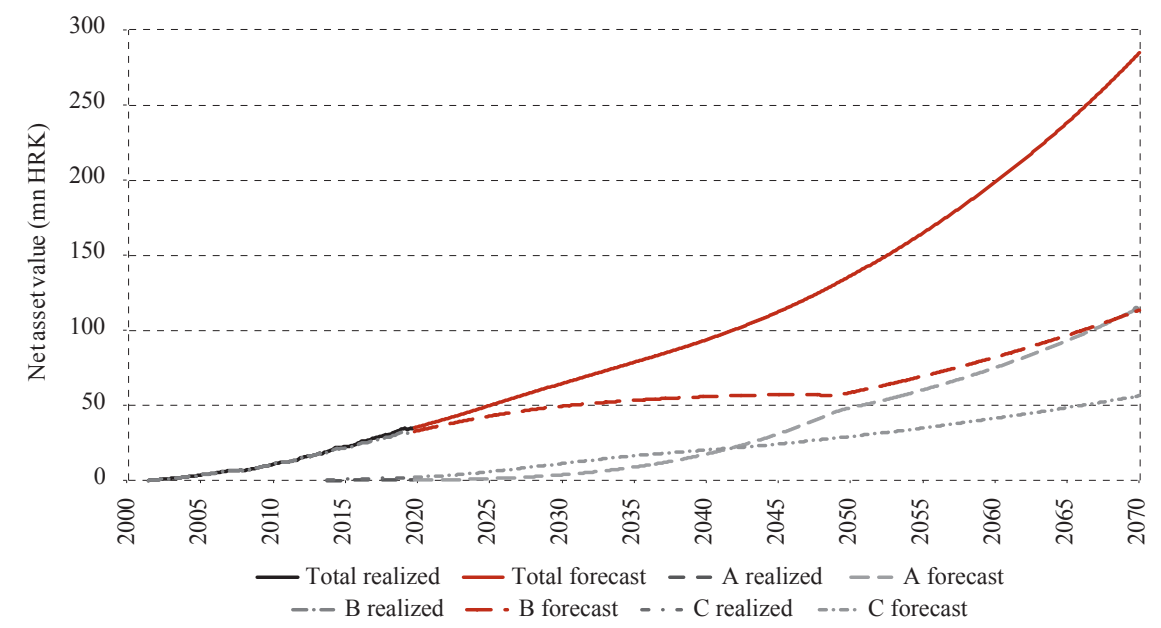

Source: Authors'own calculations.

Previously, we indicated that the above stated conclusions on net inflows for MPFs depend on the assumptions of three parameters that are embedded in the calculations, namely, rate of change in number of newcomers to the $2^{\text {nd }}$ pillar, rate of change of gross salaries and MPFs/long-term returns. Here, we are not going to stress long-term returns because decreasing returns imply also a decreasing amount of accumulated savings (liabilities in collective investment schemes usually follow the value of assets). Rather, we analyse unfavourable changes in the first two parameters, as one of them can be considered essentially demographic (newcomer growth rate) and the other economic (gross salary growth rate).

The effect of a lower newcomer annual growth rate than assumed in the baseline scenario $(0.3 \%)$ can be seen in figure 1 where we use a negative annual growth rate of $0.2 \%$. Total membership starts to decrease after two decades and category A funds membership is highly affected (effects for category B and C funds are not shown as they are not significant). At the same time, overall MPF net inflows decrease significantly after 2050 with the main contribution coming from category A funds (B and $\mathrm{C}$ are not depicted for the same reason as before). Here, the conclusion is that in the future, category A funds also might experience diminishing cash flows. The effect on asset values is not significant in this case. 
The effect of a lower annual gross salary growth rate than assumed in the baseline scenario $(1.0 \%)$ on net inflows is almost the same as in the previous scenario, if we assume gross salary growth rate of $0.5 \%$. However, the combined effect of negative newcomer annual growth rate of $0.2 \%$ and lower annual gross salary growth rate of $0.5 \%$ pushes net inflows of category A funds towards slightly negative values. Our analysis shows that future cash flows of category A funds are quite sensitive to demographic and economic factors. In the following chapter, we analyse the liquidity shortages implications for asset allocation of MPFs and subsequently to their expected returns.

\subsection{LIQUIDITY-DRIVEN CHANGES IN ASSET ALLOCATION FOR MANDATORY PENSION FUNDS}

In order to address liquidity shortage in a particular MPF, we assume the simplest choice that in a future could be performed by fund managers, and that is the reallocation of assets with lower liquidity (presumably domestic) to assets of higher liquidity (presumably developed markets) in order to minimize market impact on asset prices. Our assumption also implies we do not expect in a near future that domestic assets will improve their liquidity as compared to developed market assets.

We also note that asset reallocation is not the only choice to reduce liquidity issues as high fixed income allocation funds have the advantage of collecting accrued interest on those securities, which may strongly reduce liquidity issues. Moreover, a gradual switch from growth stocks to value stocks that pay dividends more regularly may help to reduce the liquidity burden for the equity part of the pension funds' portfolios. However, since it is not possible reliably to estimate the liquidity of asset classes in the future, or future cash flows generated by coupons of fixed income instruments and dividends of shares, in the following we will simply assume that reallocation will occur in a certain amount.

Therefore, in table 7 we propose expected changes in asset allocation for particular MPF categories, where we reallocate, with respect to compositions denoted in table 5 , mostly in category B funds, due to the higher rate of negative cash flows. We note that reallocation amounts do not depend only on expected cash flows, they depend on and are tightly interconnected with the liquidity of particular asset classes and also depend on the value of assets of particular pension fund in that period.

\section{TABLE 7}

Expected liquidity-driven asset allocation of MPFs in asset classes (in \% of funds' assets)

\begin{tabular}{|c|c|c|c|c|}
\hline & & $\mathbf{A}$ & B & $\mathbf{C}$ \\
\hline \multirow{2}{*}{ HR } & Fixed income & 25 & 45 & 80 \\
\hline & Equity & 20 & 5 & 0 \\
\hline \multirow{2}{*}{ DM } & Fixed income & 15 & 25 & 20 \\
\hline & Equity & 40 & 25 & 0 \\
\hline Total & & 100 & 100 & 100 \\
\hline
\end{tabular}

Source: Estimations by the authors. 
The proposed reallocations resulted in risk/return profiles shown in table 8. As expected, the returns of all MPF categories are lower than returns that would exist if there were no liquidity shortages. The difference between portfolio returns obtained after liquidity-driven reallocation and those without expected liquidity shortage denoted as liquidity premium - is negative for MPFs: for category A funds it is equal to $12 \mathrm{bp}$, for category $\mathrm{B}$ funds it is $13 \mathrm{bp}$ and for category $\mathrm{C}$ funds it amounts to $5 \mathrm{bp}$.

\section{TABLE 8}

The expected returns and volatilities of MPFs after liquidity-driven reallocations (in \%, annualized)

\begin{tabular}{|c|c|c|c|}
\hline Expected & A & B & $\mathrm{C}$ \\
\hline Risk & 9.63 & 5.86 & 4.52 \\
\hline Return & 3.73 & 2.48 & 1.40 \\
\hline
\end{tabular}

Source: Authors'own calculations.

These results depend on assumed expected long-term returns for particular asset classes and the amount of reallocations needed to reduce funds' liquidity risk. The obtained results also imply that in the fourth and fifth decade of this century category B funds are expected, not just to forgo the usual positive liquidity premium, but also to bear a negative liquidity premium. The same disadvantage could be also expected for category A funds in the event of adverse demographic or economic scenarios, but not in a near future.

In the following chapters, we analyse the expected cash flows for voluntary pension funds in Croatia and implications for their future asset allocations.

\section{VOLUNTARY PENSION FUNDS}

\subsection{SHORT OVERVIEW AND DEVELOPMENT}

Open-ended voluntary pension funds (OVPFs) and closed-ended voluntary pension funds (CVPFs) in Croatia, the $3^{\text {rd }}$ pillar of the multi-pillar pension scheme, were introduced in 2002 together with the MPFs. OVPFs are available to everyone, i.e. membership is allowed to anyone who wants to pay contributions on a voluntary basis. On the other hand, CVPFs have a sponsor (a company, association of a profession or a trade union) that has an obligation to pay contributions for members of closed-ended fund. At first, only OVPFs were established, but a few years later, the first CVPFs were formed. As of the end of 3Q 2020 there were 8 OVPFs and 20 CVPFs in Croatia, managed by four pension companies, with more than 380 thousand members (336 thousand in OVPFs) and HRK 6.3 billion (EUR 835 million) of AuM (HRK 5.2 billion in OVPFs).

The risk profiles of OVPFs are not regulated by the law as mandatory funds are. Rather, management companies defined OVPFs' risk profiles and offered them on the market. Several management companies have established OVPFs that vary in their risk profiles, from balanced to conservative, in a way similar to that of the risk profiles of the A-B-C categories of the $2^{\text {nd }}$ pillar. In the case of CVPFs, the risk 
profile of a fund, together with the targeted asset allocation, is subject to an agreement between a management company and a sponsor.

To encourage savings in VPFs, the Croatian state has provided two benefits for their members: state incentives on contributions paid and tax relief. However, those benefits have been changed several times since the beginning of the pension reform which also affected cash flows of the VPFs.

First, voluntary pension savings were encouraged by $25 \%$ of state incentives on contributions paid to a fund, up to a maximum of HRK 1,250 per person in one calendar year. In 2011, the state incentives were reduced to $15 \%$ up to a maximum of HRK 750 per member per year. The reduction of incentives influenced VPFs' cash flows through the smaller inflow of the incentives themselves, and additionally by discouraging new payments as the voluntary pension savings become less attractive. However, in 2011, 32\% members fewer than the year before enrolled in OVPFs. Second, at the beginning, there was tax relief for all members' contributions up to HRK 12,000 per year, together with life insurance and supplementary health insurance premiums paid in the same year. However, tax relief for members was abolished in 2010 and a new tax relief was introduced for employers who pay contributions to VPFs on behalf of their employees, up to HRK 6,000 per year.

When a member retired from the $3^{\text {rd }}$ pillar, if she/he had used a tax relief, she/he had to pay a tax on insurance income, amounting to $15 \%$ of the tax relief used. This tax burden lasted from 2002 to 2010 and then was reduced to $12 \%$. With the latest amendments to the law in 2019, insurance income tax was abolished, so everyone who used tax relief no longer have to pay any income tax, and that was an incentive by itself. Although the income tax paid by the members was not significant, regulatory changes of this incentive positively affected and stimulated both employers and members to save in VPFs, if for nothing else, then for the sake of simplifying the process.

The cash flows of VPFs were also affected by legislative changes in 2014, which later changed further in 2019, due to the extra possibilities created for the pay-outs of accumulated savings from the $3^{\text {rd }}$ pillar. Until 2010, all members who decided to retire had to transfer their accumulated savings to a pension insurance company. In 2010, legislative changes required only members' savings above HRK 10,000 (approx. EUR 1,320) to be transferred to a pension insurance company, otherwise savings could be paid out directly to members. After major legislative changes in 2014, management companies had to provide the possibility of payments in the form of a variable annuity (i.e. unit linked), paid through VPF at least in period of 5 years, for those members with savings up to HRK 50,000 (approx. EUR 6,600), and along with an already established lump-sum payment up to HRK 10,000. This legislative change had a significant influence on VPFs' cash flows since the majority of members who decided to opt out from the $3^{\text {rd }}$ pillar had chosen that opportunity. With the latest changes in 2019 , the maximum amount was increased to 
HRK 100,000 (approx. EUR 13,200), and was provided to everyone regardless of the amount of accumulated savings. With possibility of providing variable annuities, VPFs could delay the pay-outs, thus seemingly improving the expected cash flows. Furthermore, with the latest legislative changes a lump-sum payment up to HRK 10,000 is no longer possible for newcomers which also constitutes a positive influence on VPFs cash flows.

The earliest retirement age was initially set as up to 50 years of age. With the 2019 legislative changes, the retirement age from $3^{\text {rd }}$ pillar has been changed from 50 years to 55 years, however also only for newcomers. Therefore, it will take a significant period when this shift in retirement age start to improve VPF cash flows.

As contributions to VPFs are voluntary, it is very important to observe past developments and the behaviour of members in times of crisis. The net inflows to OVPFs from the beginning were always positive. Observing the period from 2006 (figure 4), we can conclude that the number of members, the amount of contributions and assets under management has grown steadily, but not at equal growth rates.

\section{Figure 4}

OVPFs membership base (left axis, in 000), AuM (left axis, in EUR mn) and new members growth rate (right axis, in \%)

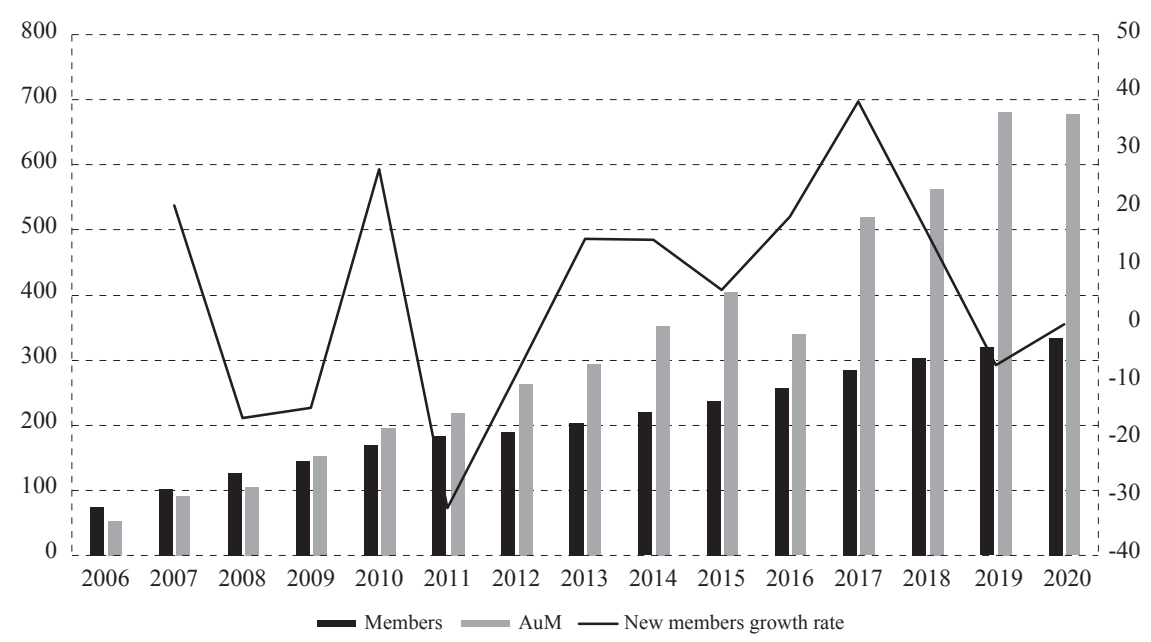

Source: HANFA reports.

During political, economic or financial crises capital markets almost regularly respond with low or negative returns. OVPFs' total membership base, which grew at an average rate of $5.9 \%$ per year, during the periods of crises, e.g. between 2008-2009 and 2011-2012, recorded negative growth rates (2008: -16.3\%, 2009: $-14.5 \%, 2011:-31.9 \%, 2012:-8.6 \%$ ). Moreover, during the same period, an increased number of members decided to use their accumulated savings from OVPFs. When compared with the year before, the increase in withdrawals was 
$83 \%$ in 2008, 124\% in 2009 and 148\% in 2012, which is more than the average long-term withdrawal rate of $44 \%$. Also, members' contributions to OVPFs usually decrease during crises (total contributions paid in 2009 was down 5\% and in 2012 it was down 7\% from the previous year). Such events have a strong impact on expected VPFs cash flows and have to be taken into account by fund managers during the process of establishing strategic asset allocations of VPFs.

Presumably, the most important impact on expected VPFs cash flows is made by the retirement age, which is here quite unpredictable (up to the estimation from historical data). Moreover, there are no clear resemblances between retirement age in the $1^{\text {st }}$ and $2^{\text {nd }}$ pillar (which occur at the same time) and retirement age in the $3^{\text {rd }}$ pillar. Although the design of multi-pillar pension scheme assumes an equal retirement age for every pillar (currently 65 years of age), it is not obvious why the $3^{\text {rd }}$ pillar should follow the same accumulation-retirement path as the first two pillars.

The goal of the $3^{\text {rd }}$ pillar is not just to provide an additional annuity - it is also designed to provide an option for postponing an early retirement from first two pillars in the event of disability or job loss, or simply due to decreasing salary or increased costs of living, in the period close to retirement. Therefore, in order to address the impact of the retirement age in the $3^{\text {rd }}$ pillar on expected cash flows, it is important to observe the age structure of VPF members, the ratio of members younger and older than 50 years of age, and their share in total assets of VPFs. We notice that the share of people older than 50 years of age in OVPFs has increased over time; the share of people younger than 50 in 2010 was $77.3 \%$ while as of $3 \mathrm{Q}$ 2020 the ratio of younger to older people is $60 \%$ to $40 \%$.

\section{Figure 5}

Trend in age structure of OVPFs in Croatia - growth rate of members under 50 years and members over 50 years old (in \%)

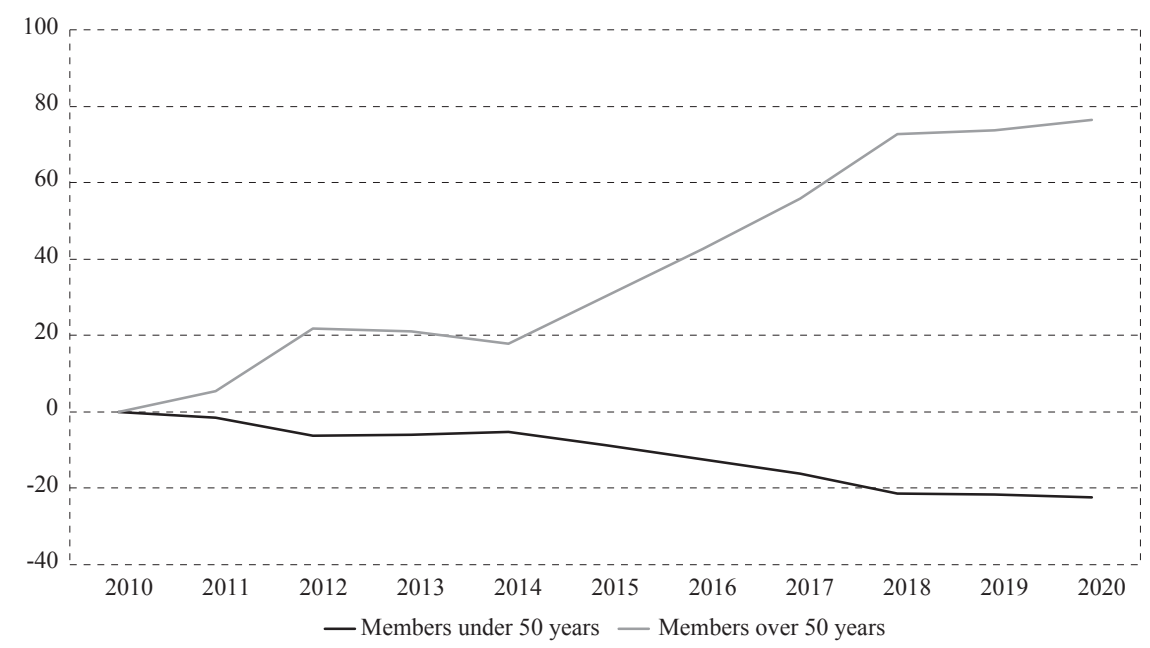

Source: HANFA reports. 
In the following, we only analyse the structures of OVPFs since data on CVPFs were not widely available until very recently. Observing the asset allocation of OVPFs' portfolios from 2006 until 3Q 2020, we notice that the allocation into domestic assets has been decreasing, while allocation in foreign assets has been increasing. As of the end of 3Q 2020, 83\% of total assets were allocated to the domestic market. Here, we reiterate that one of the main reasons for such asset allocation are the good results that the funds achieved by investing in domestic bonds during the period from 2002 to 2020. Also, VPFs allocation to equities, both domestic and foreign, has been increasing over time. As the end of 3Q 2020, OVPFs exposure to equities was over $22 \%$. This gradual change in OVPFs asset allocation reflects, among others, the development of the Croatian capital market. However, fixed income instruments still dominate in OVPFs' asset allocation structure.

In the following analysis, since the structures of open-ended VPFs are very similar to A-B-C categories of MPFs, we use the same asset classes for VPFs as we used for MPFs. Also, the expected long-term returns, volatilities and correlations for those asset classes are the same as for MPFs (tables 2 and 3).

In order to assess the unique asset allocation structure of all Croatian OVPFs, we analyse their risk profiles and market shares in terms of net asset value. Consequently, we assume a moderately conservative asset allocation structure with the assumed targeted asset allocation shown in table 9. In addition, assumed targeted asset allocation is further divided between Croatian and developed markets as shown in table 10 .

\section{TABLE 9}

Expected asset allocation of OVPFs in equity and fixed income asset classes (in \% of funds'assets)

\section{OVPF}

\begin{tabular}{ll}
\hline Equity & 25 \\
\hline Fixed income & 75 \\
\hline
\end{tabular}

Source: Estimations by the authors.

\section{TABLE 10}

Expected asset allocation of OVPFs in Croatian and developed market asset classes (in \% of funds' assets)

\begin{tabular}{|c|c|c|}
\hline & & OVPF \\
\hline \multirow{2}{*}{ HR } & Fixed income & 45 \\
\hline & Equity & 15 \\
\hline \multirow{2}{*}{$\mathrm{DM}$} & Fixed income & 30 \\
\hline & Equity & 10 \\
\hline Total & & 100 \\
\hline
\end{tabular}

Source: Estimations by the authors. 
Based on the assumptions on expected returns, risks, correlations and the asset allocations of OVPFs' portfolios, we obtain the expected return and risk for VPFs that are shown in table 11 .

\section{TABLE 11}

The expected returns and volatilities of OVPFs (in \%, annualized)

\begin{tabular}{lc} 
Expected & OVPF \\
\hline Risk & 5.41 \\
\hline Return & 2.38 \\
\hline
\end{tabular}

Source: Authors'own calculations.

\subsection{LONG-TERM CASH FLOW OF VOLUNTARY PENSION FUNDS}

When simulating the long-term cash flows of VPFs, one has to take it into account that, unlike to MPFs, VPFs do not follow a life-cycle path. Furthermore, the most important parameters influencing long-term cash flows of VPFs can be only assumed or asserted from the data as they are not strictly stipulated. For this analysis, we used data from published reports on VPFs (HANFA reports) and data from the Raiffeisen Voluntary Pension Fund database. We assume that the sample size of that fund (market share $30.18 \%$ as of 3 Q 2019), similarly to assumptions for MPFs, is high enough for conclusions drawn from this source to be applicable to all Croatian OVPFs. The baseline scenario assumes a steady development of voluntary pension savings, i.e. a linear growth of most factors influencing cash flows.

As already mentioned, the age structure of members in VPFs is very important. The fact that total membership is constantly changing in favour of older members leads us to consider the further aging of VPF members. The rate at which this change is projected to occur in baseline scenario is $0.2 \%$ per year, decreasing for those younger than 50 and increasing for those older than 50 . At the same time, it is projected that the share of those over 65 in total membership will decrease by $0.1 \%$ per year, as we assume that after retirement from the $1^{\text {st }}$ and $2^{\text {nd }}$ pillar most of them will naturally want to retire from the $3^{\text {rd }}$ pillar as well.

As a consequence of the change in age structure, we anticipate an increase of the share in total asset of those who have more than 60 years at a rate of $0.1 \%$ per year. Currently, they hold a $50.1 \%$ share in total assets. An increase of $0.1 \%$ per year will result in a $52.6 \%$ market share in 2070 . On the other hand, we anticipate a $0.02 \%$ reduction in the share of total assets of members over 65 years of age. The number of those who will exit VPFs every year is the most influential factor of the long term cash flow forecast. As members stay longer in a fund, they have more accumulated funds and, as they are older on average, more of them will leave. Therefore, it is expected that pay-outs will increase over time. Also, we have to take into account older members with no balance or a very small balance on their account. Finally, we assume $50 \%$ of those older than 65 will opt out from the $3^{\text {rd }}$ pillar every year. 
As of 3Q 2020 the share of members older than 50 who decided to opt out was approximately around $10 \%$ (average since 2006). As the retirement age in VPFs has increased to 55 (only for newcomers from 2019 further), this will influence the share of opt-outs among those older than 50, however with a lower intensity at first. Therefore, we predict $12 \%$ of those older than 50 will opt-out from VPFs every year. The assumed share of opt-outs and their share in the total assets of VPFs, give us projected amounts for pay-outs.

In simulation of the membership base, beside those who will opt out, we assume the rate of increase of new members in VPFs. In a baseline scenario, we assume a (not overly optimistic) growth of membership by $2 \%$ every year. The assumption is based on the historical developments where the growth rate of new members in the period from 2006 on, varied from $-32 \%$ to $+38 \%$, with the average rate of $5.9 \%$. For expected contributions we assume an average payment of HRK 2,000 per year per member, which is a calculation based on the average payments of all members since 2006. We also assume that state incentives in the future will amount to $15 \%$, and the right to state incentives is exercised by $81 \%$ of members, which is also a calculation based on data for the last 5 years. Results of our simulation for long-term net inflow and assets of VPFs are shown in figure 7.

\section{Figure 6}

VPFs net inflow (left axis, in EUR mn), VPFs net inflow pessimistic (left axis, in EUR mn), VPFs net asset value (right axis, in EUR bn) and VPFs net asset value pessimistic (right axis, in EUR bn)

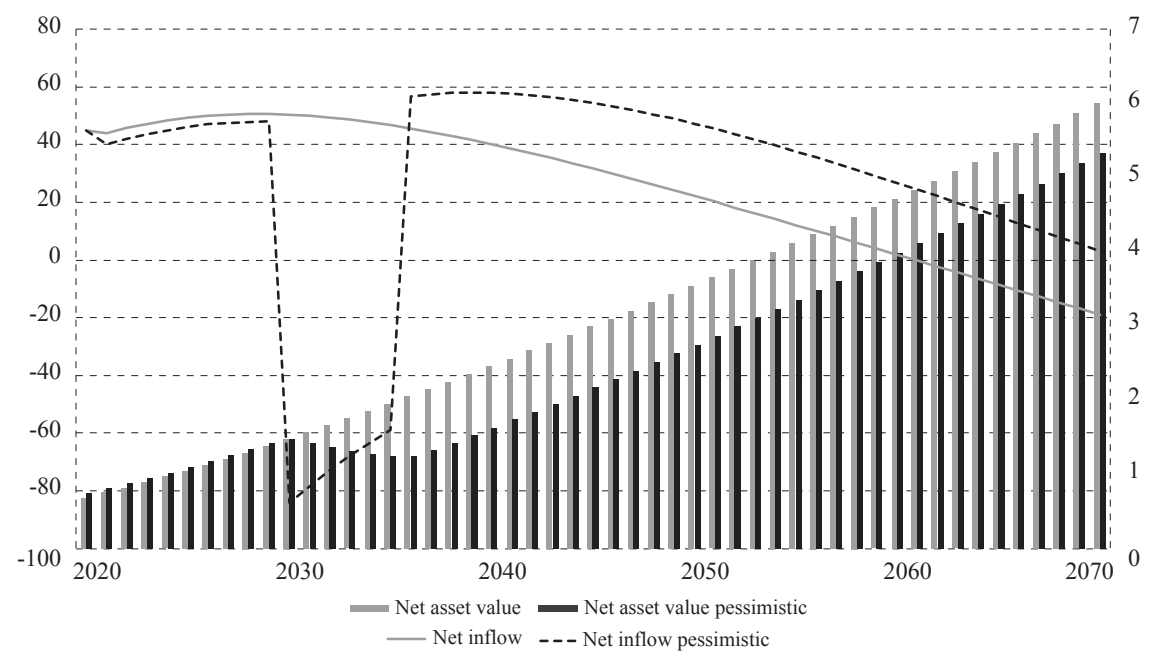

Source: Authors'own calculations.

From figure 6 we see how, after reaching a peak around 2030, due to increasing pay-outs over the years, net inflow records a steady decline in the following period. Around 2060, net inflow becomes negative, i.e. pay-outs exceeds contributions to VPFs. On the other hand, net asset value growth is steady throughout 
the years until 2070. If the time period were extended for another decade, we would see that net inflow would return to positive territory after 2080. However, we cannot exclude unsustainability of the system in a very long run due to the sensitivity of simulations to input parameters.

\section{Figure 7}

$V P F s$ liquidity requirement (left axis, in EUR mn), VPFs liquidity requirement pessimistic (left axis, in EUR mn), share of liquidity requirement in AuM (right axis, in \%), share of liquidity requirement pessimistic in AuM (right axis, in \%)

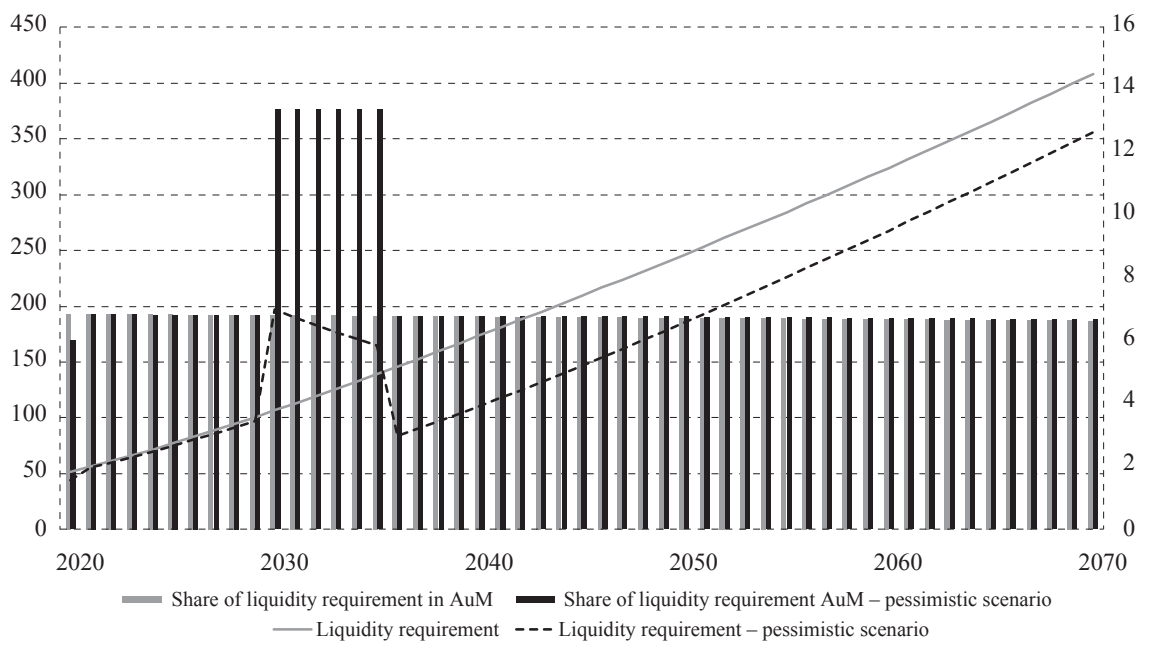

Source: Authors'own calculations.

The nominal growth of assets required for pay-outs and their share in total AuM are shown in figure 7. In the case when more assets are needed for liquidity, the targeted asset allocation of a VPF is expected to change. In that case, due to higher requirements for additional liquidity, the expected return of the fund is lower since highly liquid assets generally do not have attractive returns. However, in this scenario, the share of liquidity requirement in AuM decreases slightly over the years, and remains in the range between $6.85 \%$ and $6.50 \%$. The OVPFs in a baseline scenario would not have to change their risk profile regardless of the nominal liquidity requirement increase.

In a pessimistic scenario we analyse the influence of unfavourable economic developments on the long-term cash flow of VPFs. This situation could be caused by some economic crisis, serious demographic issues, distrust in the financial or pension system, etc. We assume that this period will happen in 2031 and last for 6 years (stress period). For other periods, assumptions will stay the same as in baseline scenario. As already confirmed, during the crisis period, VPFs will experience a lower growth rate of newcomers, lower contributions and most important, increased demand for pay-outs. For the pessimistic scenario we use adverse values of parameters for this particular 6 year period. We assume that opt-outs of 
those older than 50 will rise to $25 \%$ (baseline scenario: $12 \%$ ), growth rate of newcomers decreases to $1 \%$ (baseline scenario: $2 \%$ ), and average payment falls to HRK 1,500 (baseline scenario: HRK 2,000). Our analysis shows the net inflow is very sensitive to those factors. Dashed lines in figure 6 show how net inflows look during the stress period, i.e. how suddenly they become negative.

In figure 7 it is shown, also with a dashed line, how the liquidity requirement rises sharply, both nominally and in terms of total assets. It is immediately clear that VPFs cannot maintain the same investment structure and will have to reallocate to assets with higher liquidity. Therefore, the targeted asset allocation structure changes and the expected return decreases during the stress period.

\subsection{LIQUIDITY-DRIVEN CHANGES IN ASSET ALLOCATION FOR VOLUNTARY PENSION FUNDS}

The liquidity issue for VPFs may force fund managers to reallocate VPF assets from lower liquidity assets (presumably domestic) to higher liquidity assets (presumably developed markets), as we discussed already for MPFs, in order to minimize market impact on asset prices during the crisis period. Table 12 shows the assumed new asset allocation for VPFs. Consequently, expected returns and volatilities for this new VPF allocation are shown in table 13.

\section{TABLE 12}

Expected liquidity-driven asset allocation of OVPFs in asset classes (in \% of funds'assets)

\begin{tabular}{|c|c|c|}
\hline & & OVPF \\
\hline \multirow{2}{*}{ HR } & Fixed income & 35 \\
\hline & Equity & 10 \\
\hline \multirow{2}{*}{$\mathrm{DM}$} & Fixed income & 40 \\
\hline & Equity & 15 \\
\hline Total & & 100 \\
\hline
\end{tabular}

Source: Estimations by the authors.

\section{TABLE 13}

The expected returns and volatilities of OVPFs after liquidity-driven reallocations (in \%, annualized)

\begin{tabular}{lc} 
Expected & OVPF \\
\hline Risk & 5.08 \\
\hline Return & 2.28
\end{tabular}

Source: Authors'own calculations.

The lower return of OVPFs is a result of liquidity shortages. Due to the move in asset allocation structure, the difference between returns obtained after liquiditydriven reallocation and those without expected liquidity shortage (the liquidity premium) amounts to $-0.10 \%$ during the stress period. We conclude that during 
period of crisis, VPFs may deviate from their targeted assets allocation strategies, which ultimately may lead to reduced returns that are reflected on the savings of all members.

The results obtained here for OVPFs can be also applied for CVPFs after accounting for eventual differences in age structures of their members as well as specific risk profiles and size in net asset values.

\section{CONCLUSION}

In this paper we analysed Croatian $2^{\text {nd }}$ and $3^{\text {rd }}$ pillar pension scheme long-term cash flows and liquidity-driven changes in asset allocation that are expected to induce negative liquidity premiums for pension funds. For mandatory pension funds, long-term cash flow fluctuations are determined by the age distribution of affiliates at the start of the $2^{\text {nd }}$ pillar in 2020, transition to the proxy life-cycle scheme introduced in 2014, as well as the change in the default fund for indecisive newcomers in 2019. Although calculations are based on data from mandatory pension funds managed by one fund management company, they are expected to be valid for all $2^{\text {nd }}$ pillar pension funds in Croatia.

Simulations are carried out on the membership base for all three categories (A, B and C) of mandatory pension funds taking into account the statutorily determined life-cycle path for transferring between particular fund categories, as well as the enrolment rate in category A funds as the main parameter for the long-term demographic sustainability of $2^{\text {nd }}$ pillar. From the membership base, simulations are carried out on net inflows by taking into account gross salary growth rate as well as accumulated savings for particular cohort groups. Also, in order to calculate accumulated savings, the expected long-term returns of mandatory pension funds are determined by assuming portfolio allocation of a particular category fund to four different asset classes (domestic and developed markets, equity and fixed income) with respective expected returns, volatilities and correlations.

The obtained long-term net inflows to mandatory pension funds show that category B funds are expected to sustain a relatively long period of negative cash flows. Assuming that liquidity shortages are addressed by reallocation from less liquid domestic assets to substantially more liquid assets on developed markets, a negative liquidity premium is calculated for all three categories, i.e. under assumed reallocations, for category A it is $12 \mathrm{bp}$, for category B funds it is $13 \mathrm{bp}$ and for category $\mathrm{C}$ funds it amounts to $5 \mathrm{bp}$. Also, in a scenario of adverse demographic or economic conditions, modelled through negative enrolment rate to the $2^{\text {nd }}$ pillar and a lower gross salary rate increase, we showed a significant sensitivity of net inflows for A and B categories that could further enlarge the negative liquidity premiums obtained in the baseline scenario.

We also note that asset reallocation is not the only way to reduce liquidity issues. High fixed income allocation funds have the benefit of collecting accrued interest 
on those securities, which may strongly reduce liquidity issues. Moreover, a gradual switch from growth stocks to value stocks that pay dividends more regularly may help to reduce the liquidity burden for the equity part of the pension funds' portfolios. Nevertheless, it is almost certain that in a decade, pension fund managers will have to adjust portfolios of category B funds in a manner suitable to address the liquidity shortage for the foreseeable next two decades, which could have significant influence on the domestic capital market due to the fact that Croatian mandatory pension funds are the most significant local institutional investors.

We also caution the reader that analysis provided in this paper for $2^{\text {nd }}$ pillar funds should not be viewed as a revelation of a problem, rather a challenge for future pension fund managers. We expect that the benefits gained through introduction of the life-cycle scheme in $2^{\text {nd }}$ pillar will more than compensate for the possible liquidity premium lost in a necessary path from one-size-fits-all investment vehicles to something that is a proxy for gliding path investment vehicles. Moreover, proponents of a true gliding path approach to life savings (Vukorepa, 2011, 2012; Potočnjak and Vukorepa, 2012) would probably appreciate the results presented in this article as a justification for a further pension scheme reform that has the potential to eliminate some of proxy life-cycle inefficiencies (Kovačević and Latković, 2015; Azoulay, Kudryavtsev and Shahrabani, 2016; Kudryavtsev, Shahrabani and Azoulay, 2017) or risks imposed on their beneficiaries (Kovačević and Latković, 2015).

In this paper we also analysed the net inflows of the Croatian $3^{\text {rd }}$ pillar, specifically open-ended voluntary pension funds, since data on closed-ended are not widely available. Although calculations for the $3^{\text {rd }}$ pillar are also based on data from a voluntary pension fund managed by one fund management company, they are expected to be valid for all open-ended voluntary pension funds in Croatia due to the market share of this fund. In the short overview of the $3^{\text {rd }}$ pillar in Croatia, we presented its historical perspective and the most important legislative changes that influenced $3^{\text {rd }}$ pillar cash flows, i.e. retirement age, tax treatment and incentives on savings in the $3^{\text {rd }}$ pillar. The retirement age in the $3^{\text {rd }}$ pillar or withdrawals (optouts) is the most important factor that determines voluntary pension funds' cash flows. Besides that, as well as the enrolment rate and contribution rate to $3^{\text {rd }}$ pillar funds, their cash flows are also dependent on new possibilities introduced in 2014 for pay-outs in a form of variable annuity payments.

By analysing behaviour of members in the $3^{\text {rd }}$ pillar during periods of crises, we concluded that such events tend to decrease enrolment rates (negative growth rate of newcomers) and average contributions, while more members will decide to opt out. We also analysed the asset allocation of open-ended voluntary pension funds' portfolios from 2006 until 3Q 2020. In this paper we assumed a moderately conservative asset allocation for a typical open-ended voluntary pension fund with an assumed distribution between Croatian and developed markets equity and fixed income instruments. 
We carried out simulations of cash flows for two scenarios - a baseline scenario and an adverse one. The baseline scenario assumed a steady development of voluntary pension savings with model parameters that match current trends for $3^{\text {rd }}$ pillar open-ended funds. Result of the baseline scenario simulation shows how, after reaching a peak around 2030, due to increasing pay-outs over the years, net inflow records a steady decline and becomes negative around 2060 when pay-outs exceed contributions. On the other hand, net asset value growth is steady throughout the years until 2070. However, we couldn't exclude unsustainability of the system in a very long run due to the sensitivity of simulations to input parameters. However, in a baseline scenario net inflow would return to positive territory after 2080 if we extended the simulation for another decade. We also showed the nominal growth of assets required for pay-outs and share of those assets in net asset value of a fund. We calculated that the liquidity requirement for $3^{\text {rd }}$ pillar openended funds in terms of net asset value decreases slightly over the years, and remains in the range between $6.85 \%$ and $6.50 \%$. We also concluded how in the baseline scenario $3^{\text {rd }}$ pillar open-ended funds are expected not to change their risk profiles regardless of the nominal increase of liquidity requirements.

In a more adverse scenario we analysed the influence of unfavourable economic developments on long-term cash flows of $3^{\text {rd }}$ pillar open-ended funds. We assumed such events will happen for a relatively short period and for other periods we left assumptions the same as in the baseline scenario. We also assumed that opt-outs of those older than 50 will rise significantly, the growth rate of newcomers will decrease and the average contribution will fall substantially. An analysis showed how net inflows during the stress period suddenly become negative, liquidity requirement rises sharply, both nominally and in terms of net asset value. We concluded that under those circumstances, $3^{\text {rd }}$ pillar open-ended funds are expected to reallocate assets to more liquid investments. Such a reallocation will decrease expected returns of $3^{\text {rd }}$ pillar open-ended funds and induce a negative liquidity premium that, under assumed reallocations, amounts to $-0.10 \%$ during the stress period. Negative liquidity premium as it is presented in this article should be acknowledged only as information and not a recommendation to legislators or supervisors as this issue requires further thorough analysis.

\section{Disclosure statement}

No potential conflict of interest was reported by the authors. 
1. Azoulay, Y., Kudryavtsev, A. and Shahrabani, S., 2016. Accumulating approach to the life-cycle pension model: practical advantages. Financial Theory and Practice, 40(4), pp. 413-436. https://doi.org/10.3326/fintp.40.4.3

2. Dimson, E., March, P. and Staunton, M., 2020. Credit Suisse Global Investment Returns Yearbook 2020. Zurich: Credit Suisse Research Institute.

3. Draženović, B., Hodžič, S. and Maradin, D., 2019. The Efficiency of Mandatory Pension Funds: Case of Croatia. South East European Journal of Economics and Business, 14(2), pp. 82-94.

4. HANFA, 2020. HANFA reports. Zagreb: Croatian Financial Services Supervisory Agency.

5. Horizon Actuarial Services, 2020. Survey of Capital Market Assumptions: 2020 Edition. Atlanta: Horizon Actuarial Services.

6. Kovačević, R. and Latković, M., 2015. Risk analysis of the proxy life-cycle investments in the second pillar pension scheme in Croatia. Financial Theory and Practice, 39(1), pp. 31-55. https://doi.org/10.3326/fintp.39.1.2

7. Kudryavtsev, A., Shahrabani, S. and Azoulay, Y., 2017. Frequency of Adjusting Asset Allocations in the Life-Cycle Pension Model: When Doing More Is Not Necessarily Better. Bulletin of Applied Economics, 4(1), pp. 13-33.

8. Latković, M. and Liker, I., 2009. Sensitivity Analysis of the Pension System. Financial Theory and Practice, 33(4), pp. 445-461.

9. Matek, P. and Radaković, M., 2015. Is active management of mandatory pension funds in Croatia creating value for second pillar fund members? Financial Theory and Practice, 39(3), pp. 245-278. https://doi.org/10.3326/fintp.39.3.1

10. Matek, P., Lukač, M. and Repač, V., 2016. Performance appraisal of Croatian mandatory pension funds. Financije i pravo, 4(1), pp. 7-30.

11. Novaković, D., 2015. Evaluation of the financial performance of pension funds in Croatia. Ekonomski vjesnik/Econviews - Review of Contemporary Business, Entrepreneurship and Economic Issues, 28(1), pp. 199-212.

12. Potočnjak, Ž. and Vukorepa, I., 2012. Modeling of life-cycle portfolios in capital-funded pension systems with defined contributions. Economic Trends and Economic Policy, 22(130), pp. 29-59.

13. Šorić, K., 2000. Izračun mirovine na temelju individualne kapitalizirane štednje. Računovodstvo i financije, (5), pp. 75-87.

14. Vukorepa, I., 2011. Mirovinski sustavi: kapitalno financiranje kao čimbenik socijalne sigurnosti. Doctoral dissertation. Zagreb: Faculty of Law.

15. Vukorepa, I., 2012. Mirovinski sustavi - kapitalno financiranje kao čimbenik socijalne sigurnosti. Zagreb: Faculty of Law.

16. Zakon o dobrovoljnim mirovinskim fondovima (Voluntary Pension Funds Act), NN 19/14, 29/18, 115/18. Zagreb: Narodne novine.

17. Zakon o obveznim i dobrovoljnim mirovinskim fondovima (Mandatory and Voluntary Pension Funds Act), NN 49/99, 63/00, 103/03, 177/04, 140/05, 71/07, 124/10, 114/11, 51A/13. Zagreb: Narodne novine.

18. Zakon o obveznim mirovinskim fondovima (Mandatory Pension Funds Act), NN 19/14, 93/15, 64/18, 115/18, 58/20. Zagreb: Narodne novine. 